\title{
A CENTURY AND MORE OF ITALIANS IN TORONTO: AN OVERVIEW OF SETTLEMENT
}

\section{GABRIELE SCARDELLATO}

\begin{abstract}
Summary: Through the use of various published and original sources this study outlines the reception and settlement of Italian immigrants in a modern Canadian urban environment. Substantial Italian migration and immigration to Toronto began in the late nineteenth century. The first migrants and immigrants were dispersed across at least four relatively distinct, inner-city neighbourhoods. Overtime, and in particular after World War Two, one of these neighbourhoods grew to become one of the largest settlements of its type outside of Italy. Now in the process of gentrification, the area known as College Street Little Italy served a pivotal role in the accommodation of Italian immigrants in Toronto.
\end{abstract}

When the late Robert F. Harney began to contemplate a comprehensive study on Italians in Toronto in the post-World War Two period he looked for his inspiration beyond urban studies and beyond the history of Italian migration, immigration, and settlement to works of the imagination-in particular to literature and to historiography-specifically the novels of the Italian-Cuban author Italo Calvino and the historiography of Hayden White. Over time Harney's musings about Italians and their settlement(s) in Toronto appeared in a number of related essays. These reveal interesting developments in his thought that will prove useful for the present effort. ${ }^{1}$

One of Harney's first essays on Italians in Toronto, although primarily concerned with pre-World War I history, includes in its title the suggestive term chiaroscuro-normally associated with the study of art-and opens with a paragraph on the considerable demographic and related impact of Italian immigration to "Toronto the Good" in the post-World War II period. ${ }^{2}$ The article is an abridged version of another by the same title that had appeared some nine years earlier (in the mid-1970s), when

${ }^{1}$ Part of the research on which this study is based was made possible through my tenure as the Research Fellow of the Mariano A. Elia Chair in Italian Canadian Studies, York University, and I would like to thank the directors of that institution for their support.

${ }^{2}$ Harney, "Chiaroscuro: Italians in Toronto, 1885-1915," pp. 44-49. 
Harney's study of migration, immigration and ethnicity was beginning to bear its first fruits. ${ }^{3}$

In the following year, he redeployed portions of the same opening paragraph, but this time for a more prosaically titled - though still speculative-essay "How to Write a History of Postwar Toronto Italia."4 In the process of describing "how to" Harney introduced the concept of "emplotment"; derived from the historiography of Hayden White. By 1987 Harney had added an essential ingredient to his essay that was borrowed from the realm of literature and the speculative questing suggested by Italo Calvino's metafictional novel If on a Winter's Night a Traveler. In this last version of his essay Harney acknowledged his debt to Calvino by connecting his new version of the essay's title to Calvino's novel and also to White's metahistorical work. "The reader will recognize the allusion to Italo Calvino's [novel] ... in the title of this essay ["If One Were to Write a History of Toronto Italia"]. From the title, he or she should gather either that I believe that I have failed to find an emplotment [for the history of Italians in Toronto after the Second World War] that works, or that I am content to suggest some of the many narratives that seem possible or ... a deeper narrative in my encounter with the chaotic mass of source material." 5 The influence of both Calvino and White is clear in Harney's suggestion of many possible narrative readings, or a possible deeper narrative, for a history of post-war Toronto Italia. ${ }^{6}$

${ }^{3}$ These early essays on Italians in Toronto predate, in fact, the foundation of the Multicultural History Society of Ontario (1976), which was one of Harney's most significant accomplishments. His early interest in Italian migration and immigration to Canada, and to Toronto in particular, suggests how important this ethnic group was for the interest that Harney would develop for the study of all immigrant and ethnic groups in Canada and for the more general study of Canadian diversity and pluralism. See, for example, one of his last works, "'So Great a Heritage as Ours'," pp. 227-270.

${ }^{4}$ Harney, "How to Write a History of Toronto Italia," pp. 61-66.

${ }^{5}$ Harney, "If One Were to Write a History of Postwar Toronto Italia," p. 64.

${ }^{6}$ According to one of his editors, part of Harney's scholarly insight into the study of immigration was his transformation of immigrants into "texts." "In the immigration process, the immigrants and their surrounding culture would become 'text,' or more precisely, 'narration,' from which would flow 'sense' and 'meaning.' Asked to contribute, the migrant himself could textualize or, as the Latin etymology suggests, weave the various elements and threads into a tapestry, an account of events and realities beyond the conventional as conceived by various elites and intermediaries." Anctil, "The Immigrant as Text," p. ix. This is a compelling insight into Harney's response to Hayden White's merging of literary the- 
Harney referred to Calvino again in a later and more general essay titled "Ethnicity and Neighbourhoods." In the latter, however, Harney turned to Calvino's Invisible Cities — which he cited at least twice-for insights on how one might write about immigrants in urban environments. In the opening passages of this study he quoted from Calvino's "superb pseudo-geography, Invisible Cities ... 'Beware of saying to them that sometimes different cities follow one another on the same site, with the same name, born and dying without knowing one another, without communication among themselves." 7 Later in this essay about immigrants and their descendants in Canadian/North American cities he reproduced a lengthy excerpt from Calvino's description of the imagined city of "Ersilia":

In Ersilia, to establish the relationships that sustain the city's life, the inhabitants stretch strings from the corners of the houses, white or black or grey or black-and-white according to whether they mark a relationship of blood, of trade, authority, agency. When the strings become so numerous that you can no longer pass among them, the inhabitants leave: the houses are dismantled; only the strings and their supports remain. ${ }^{8}$

ory and historiography in the latter's metahistorical work. It is also an interesting allusion to Calvino's description of the lives of the residents of the city of Ersilia, and the "strings" or threads that they weave in their travels across their city, for which see below.

7 Harney, "Ethnicity and Neighbourhoods," p. 92. The extract is from Marco Polo's description of the invisible city of Maurilia; Calvino, Invisible Cities, p. 30. Harney also turned to Calvino in his essay "The Immigrant City," pp. 4-6. In this text he cites Calvino's Invisible Cities in support of a challenge to Canadian hegemonic readings of the "success" of multiculturalism with particular reference to immigrants in cities. In that essay he criticized readings that presented Canadian cities as peaceable homogeneities. His preference is for a narrative driven by strife between newcomer and older resident for which Harney cites Calvino's reference to the unease felt by Romans with polyglot cities; between the old and the new and stability and change. According to Harney, Calvino felt that the Romans used the minor deities Penates and Lares to mediate the problems in polyglot cities; see Calvino, "Cities and Names 2," pp. 78-79, for the city of Leandra with its resident gods, the Lares and Penates. For another viewpoint that also suggests strife in the "practices of placemaking" see N. Harney, "The Politics of Urban Space," p. 26, in which the author supports the position that in "plural cities ... the production of a neighbourhood [by Italians or others] is not just an exercise of power over some sort of environment ... but also one inhabited by other people, with counter or emergent claims to the same spaces."

${ }^{8}$ Calvino, Invisible Cities, p. 76; Calvino's invisible city is incorrectly referenced in Harney's "Ethnicity and Neighbourhoods," p. 108, as Vasilia. 
Harney argued that the "mythical" city Ersilia could be substituted readily with various locations in Toronto including its "Junction, Cabbagetown, Ward, or Kensington Market" neighbourhoods where, he suggests, "many of the immigrants probably understood their neighbourhood and the city in much the same way" as Marco Polo's Ersilians. In other words, immigrants "weave" their narrative as they traverse the city and as they weave (their strings, of course, are the traditional colours of text on paper), using the Latin etymology of the term, they create texts that describe their experiences. ${ }^{9}$ He also suggests that "good urban historians will learn how to read a narrative in those strings and their supports" created by immigrants and then left behind. ${ }^{10}$

This is an important and compelling challenge because for Harneythe doyen of Italian-Canadian studies-it was provoked by one of the most important immigrant settlements in Toronto; namely, the neighbourhood that developed on College Street between Bathurst Street and Ossington Avenue, in the city's west side. ${ }^{11}$ What narrative, then, should we read in the strings and supports created by those Italians (and their descendants) who settled in this neighbourhood; in this "Little Italy" as now boldly declared by the banners on its streetlight poles and the Italian maps sketched in lights? Perhaps before we decide, like Harney, we should attempt to describe the strings- that is, the lives of migrants and immigrants themselves - with the awareness that by doing so we may already have chosen an emplotment and that this choice derives from a particular motivating vision or idea. We should avoid the claim that any one reading might be preferred over any other but, as Harney also insisted, we should at least try to read the experience through the eyes of its protagonists.

Harney's insistence that we emplot our narrative from the perspective of the stories woven by the immigrants themselves is particularly important for an understanding of a construct like "Little Italy." The name itself, of course, does not begin in the immigrant experience. Rather, it derives from a variety of names-many of them derogatory and demeaning-generally applied from outside of the realities of migrants and immigrants. ${ }^{12}$ Even in

${ }^{9}$ Anctil, "The Immigrant as Text," p. ix.

10 Harney, "Ethnicity and Neighbourhoods," p. 108.

${ }^{11}$ The importance of the College Street neighbourhood for Harney is also suggested by his personal life and by his family's decision in 1989 to hold his funeral service at the Church of St Francis of Assisi, in the heart of the neighbourhood.

12 See Gabaccia, "Global Geography of 'Little Italy'," for a critical and compelling 
its final form-despite apparent acceptance by immigrants themselves and certainly their descendants-it can be read as exotic and diminishing. It might also serve, though perhaps with less malicious intent than some of its predecessors, to homogenize a complex reality and in this regard even the recourse to Polo's compelling description of Ersilia might be misleading. It is important to remember, after all, that for the present study, the Ersilians themselves are not necessarily a single society or culture or people, but rather a grouping of these entities for whom generic terms like "Italian" probably obscure more than they reveal.

The inhabitants of "Ersilia" in Toronto, now known as College Street Little Italy, began to arrive in its vicinity almost at the very beginning of the mass migration and immigration of Italians to the city. Migrants and immigrants from Italy have been present in Toronto from very early in the city's history, but a large Italian-origin population did not emerge until the closing years of the nineteenth and the early years of the twentieth century. By the late 1890 s emigration rates from Italy (for all destinations) reached truly astonishing levels as Italians fled in ever larger numbers from miseria: the social and economic misery for which they could see no local solutions. At the beginning of the last century annual departure rates occasionally totalled more than half a million in a population of some 33 million. In that vast movement of people-made up both of temporary migrants (or sojourners) and immigrants-North America became the most important overseas destination. It became so just as internal economic and political conditions in Italy were changing the regions with the highest emigration rates from north to south.

Canada, of course (and Montreal and Toronto in particular), became an important destination for Italians in this period. In the early 1890 s there were only about 3,000 residents in Canada who were of Italian origin, but this figure grew substantially in the years before World War One so that by the end of Italian emigration in the 1970s it had reached about 750,000.13 At the current level of about 1.3 million, the population total reached by the end of the era of emigration has almost doubled again. Over the same period the Italian-origin population of Toronto grew from far less than 1,000 to the current total of almost 500,000. Indeed, as many have remarked, Toronto's Italian-origin population has grown to become one of the largest and most significant outside of Italy and the role of the city's

study of the emergence of "Little Italies" in North American settler colonies in particular and the pejorative connotations of the term itself.

13 Ramirez, The Italians in Canada, p. 8. 
College Street neighbourhood has proven to be crucial in that development. Almost from the beginning of their journeys to Toronto Italians developed a relatively complex pattern of settlement based on factors like their villages, towns or provinces of origin in Italy; the economic niches they were able to fill in the city; and their proximity both to places of work and to transportation facilities. The result, by the early years of the last century, was a series of at least four main settlement areas. The largest of these, and arguably the most important, was located in the area of the city then known as the Ward, a name derived from St John's Ward, one of the early city electoral districts bounded by College and Queen streets to the north and south respectively and by Yonge Street to the east and University Avenue in the west. Another concentration of Italian settlement developed further north and to the west of the Ward in the neighbourhood of Dufferin Street near Davenport Avenue and over time this settlement expanded westward to reach the West Toronto Junction and south as far as Wallace Street. A third settlement, albeit somewhat smaller than these two, developed to the east of the Ward, in the area around the intersection of Queen Street East and Parliament Street. Finally, the fourth settlement area that developed-also relatively near to the Ward-is the one that is most important for our purposes. The area bounded by College and Dundas streets on the north and south respectively and between Grace Street in the west and Euclid Avenue to the east was the original heart of College Street Little Italy and it was from this centre that it would grow to become the post-World War Two heart of Toronto Italia.

The beginnings of an Italian presence in this neighbourhood can be traced to the 1890 s and the settlements there by a number of immigrants from Calabria, in particular from the town of Rende and its surrounding municipalities in the province of Cosenza. One of the earliest of these immigrants was Salvatore Turano, who settled on Mansfield (what was then Cowan) Avenue where he established a grocery store, boarding house, and labour agency. Some of the paesani for whom he provided housing and for whom he found work-many on city road and street railway construction-also began to settle in the neighbourhood as did other entrepreneurs like Rafaelle Bartello and (somewhat later) Carmine Spizzirri, also on Mansfield Avenue, or Pasquale Molinaro who settled on Gore Street. Vincenzo Muto, another Calabrian, was also an early migrant to the area when, in 1910, he moved his tailor shop from his D'Arcy Street address, just west of the Ward, to a new location on College Street near Grace Street. At about the same time, Francesco Tomaiuolo, "one of the city's most influential padroni, who was primarily a private banker and steamship agent" also settled in the neighbourhood where he constructed 
a multi-purpose building, "a modern, decorous bank and retail outlet, and small hotel," the Venezia Hotel (later known as the Monarch), located at the corner of Henderson Avenue and Clinton Street. ${ }^{14}$ From this facility he conducted his affairs as a private banker and money changer, a travel agent, a news agent (Italian-language newspapers, calendars, postcards, and stamps), and a vendor of gramophone records and harmonicas. For a period of about two years he also published his own newspaper, Il Progresso Italo-Canadese (1929-1931), edited by his brother. Tomaiuolo's bank clientele provides a valuable insight into the population of the emerging College Street Little Italy in the first decades of the last century. Not surprisingly, more than half of them were Calabrians while others were from Basilicata, Sicily, Molise and Apulia and almost all of them had settled in the nearby streets around Tomaiuolo's Venezia Hotel.

Through the arrival of first hundreds and then thousands of immigrants, the College Street settlement grew just as the earlier concentration of Italians in the Ward dispersed. This earlier settlement and its mingling of Jews, Italians and other immigrants had served as a first reception area because of its proximity to transportation systems, affordable (if disreputable) housing, and other amenities. It was never well-accepted, however, and when city authorities began to dismantle it to make way for redevelopment-for example, the construction of the Toronto General Hospital for which land expropriations began in 1908-its inhabitants moved on and one of the destinations for Italians, as suggested by Vincenzo Muto's tailor shop, was the College Street neighbourhood. Of course, the dispersal took place over a considerable length of time and even after it had been completed "evidence" of the earlier presence, in or near the Ward, remained. In other words, some of the "supports" constructed by earlier immigrants and migrants remained: most conspicuously in the form of the church of the first Italian national parish in Toronto, Our Lady of Mount Carmel, on St Patrick Street north of Dundas Street, but also as a bronze plaque depicting a laurel crown dedicated to Italian Canadians and placed in 1922 by the Società Italo-Canadese on the Edith Cavell Monument located at the corner of College Street and University Avenue. ${ }^{15}$

${ }^{14}$ Zucchi, Italians in Toronto, pp. 110-117, for a good description of Tomaiuolo's career which ended in bankruptcy in 1931.

15 "As long-time residents of Toronto, the members of the [Società] Italo-Canadese had a strong sentimental link with the memorial's location. There, in the Elm Street neighbourhood (in the district commonly known as the 'Ward'), Toronto's first Little Italy had developed before the area was cleared to make room for the General Hospital and the Hospital for Sick Children." Principe, "Italian- 
While some of those landmarks survived and continued to attract those who had created them, others also were established for similar purposes. These, however, were created in the area that was increasingly coming to be known as home-in the vicinity of College and Clinton streetsfor more and more Italians in Toronto. In 1913, for example, as Tomaiuolo and others were establishing themselves in the neighbourhood, Italian immigrants were granted the church of St Agnes, at the intersection of Grace and Dundas Streets, as the second Italian national parish in the city. Their predecessors, Irish and other English-speaking Roman Catholics, moved further north on Grace Street to the newly constructed (1908) church of St Francis. ${ }^{16}$ In the following decade, the last during which any significant emigration occurred before the Depression and the Second World War, ${ }^{17}$ the Italian-origin population of this newer Little Italy grew to a total of about 2,500 with a "core" group of about 400 Calabrians centred, as we have seen, around Mansfield Avenue. As noted in Tomaiuolo's client list, there were also smaller groupings from other Italian regions who established themselves in the area: the Apulians also settled on Mansfield Avenue and nearby at its intersection with Manning Avenue and somewhat farther away, on Markham Street, between College and Dundas streets; immigrants from Latium (Sora, in particular) on Claremont Street; and settlers from Pisticci, in Basilicata, on Henderson Avenue and also on Euclid Avenue, south of College Street to name only the most numerous. ${ }^{18}$

Canadian Monuments," p. 3. In the language of contemporary ethnographers the creation of monuments is one of three "modes of place-making" which include "the quotidian, the calendrical and the monumental, performed by Italian Canadians that serve to locate Italianness in the landscape of a plural city and to create spatial boundaries for themselves and non-Italians to negotiate." N. Harney, "The Politics of Urban Space," p. 25.

${ }^{16}$ Zucchi, Italians in Toronto, chap. 5, for the creation of Toronto's second Roman Catholic Italian national parish; see also, Perin and Scardellato, Places of Worship in West Toronto (forthcoming). Marchetto, "The Catholic Church and Italian Immigration to Toronto," pp. 107-110, gives the date for the establishment of St Francis of Assisi as 1908, and for the creation of St Agnes as an Italian national parish as 1914.

${ }^{17}$ From the early 1920 s Canadian government restrictions on immigration severely reduced the number of new arrivals to Canada and a further reduction occurred as a result of restrictions on departures from Italy imposed under the dictatorship of Benito Mussolini in Italy (1928).

${ }^{18}$ Sturino, Forging the Chain, chap. 7, for estimates of the population and the presence of Calabrians and others; see also Zucchi, Italians in Toronto, p. 42. 
A survey of College Street between Grace and Bathurst streets conducted in 1926 reported that more than $60 \%$ of the businesses on the street were or used Italian in their names. To appreciate the vigorous growth that the neighbourhood experienced during these years we must add to the establishments that were located in the immediate vicinity of College Street itself, as well as the significant concentration of settlement that was also developing, despite the fact that immigration effectively had ended. It has been estimated that by the 1930s the Italian-origin population of this settlement stood at about 10,000 (in a city-wide total of about 13,000 according to the 1931 Canadian census). ${ }^{19}$ By the beginning of World War Two, therefore, this neighbourhood had become the heart of Toronto Italia. We can gain some precious insights, generally suggestive of everyday realities for its residents, through the memories of the descendants of the first settlers.

Dominic Vaccaro, for example, was an immigrant from the Basilicata region of Italy who worked for some time in Peterborough, Ontario, before moving to and settling in Toronto, on Bellwoods Avenue, south of Dundas Street, before World War One. An injury had left him lame and the only way he could earn a living, according to his granddaughter, Mary Caruso, was by playing the barrel organ at various street corners in the city. Like many other immigrants of the time, Vaccaro anglicized his name and became, perhaps in a self-conscious reference to his injury, Dominic Walker. By the early 1920s, when he was well established, he had developed a successful daily routine. He attended mass every morning at St Agnes Church and then at 11:00 a.m. he set off with his barrel organ, "always walking everywhere," to return eventually at midnight. Except for days "when the weather was bad and he couldn't get out" he followed his routine six days out of seven. "He'd stay the whole day at the one corner and change to another the next day. Saturday was Queen and Bathurst because of all of the shoppers in the area." This routine ensured "a good living. ... Some days he'd make a good few dollars $-\$ 12$ or $\$ 13$. A poor day was only $\$ 4$ or $\$ 5$ ..." for him and his family. His granddaughter remembers that Vaccaro was well known in his own community on Bellwoods Avenue and on the nearby streets in part because of an extended family of both maternal and paternal aunts and uncles and other relatives. ${ }^{20}$

${ }^{19}$ Simone, Italian Immigrants in Toronto, 1890-1930, p. 29 for a report of the 1926 survey, based on listings in Might's Toronto City Directory, and also for the estimate of the Italian-origin population by the 1930s.

20 Anon., "An Interview with Mary Caruso," p. 217. 
Any number of immigrant lives might be selected to illustrate the development of College Street Little Italy in the decade before the mass migration of Italians that occurred after World War Two. Two such lives in particular, however, provide us with glimpses as important as those contained in the oral history of Mary Caruso about her grandfather, Dominic (Vaccaro) Walker. Another immigrant family from Pisticci, Basilicata, settled in the neighbourhood before World War Two. Leonardo and Teresa Barbalinardo arrived in Toronto before World War One and spent some time living in difficult conditions in the Ward, moving from rooming house to rooming house. Their first child, a son who would become one of the best-known residents of College Street Little Italy, was born in one of these rooming houses, "on a kitchen table" in December 1915. The family lived in extreme poverty and eventually, like many others, moved out of the Ward to join the growing settlement near College and Clinton streets.

The son, Giovanni Barbalinardo, or Johnny Lombardi as he became known, grew up in the neighbourhood where he lived and prospered his entire life. He made a career for himself as a young trumpet player and band leader, served in the Canadian armed forces in World War Two, became a grocer at the corner of Manning Avenue and Dundas Street on his return after the war, married and started a family in the 1950s, premiered an Italian-language radio program, began his own radio station in 1966 and became a leading philanthropist. ${ }^{21}$ Part of Lombardi's importance for this study lies in the role that he, and others like him, played as a bridging generation for the immigrants who began to arrive in greater and greater numbers beginning in the $1950 \mathrm{~s} .22$

Another who played a similar role, though now perhaps less wellknown publicly, was Julius Molinaro, the son of Pasquale Molinaro, whose settlement with other Calabrians in College Street Little Italy in the second decade of the last century has already been described. Pasquale Molinaro

${ }^{21}$ Lombardi-Hartig, "A Man Called Johnny Lombardi," for a brief biography of Johnny Lombardi as remembered by his daughter.

${ }^{22}$ For Lombardi's role as the producer responsible for one of the "calendrical ... modes of place-making," that is, his creation and promotion of the annual CHIN picnic, see N. Harney, "The Politics of Urban Space," p. 33. Apparently, "place-making" can occur in the absence of an actual "place" and with an indeterminate audience. Neither the original site for the CHIN picnic, on Centre Island in Lake Ontario, nor its current location at Toronto's Canadian National Exhibition grounds located close to the shore of the same lake, is a place of "Italianness" and Italian-origin participants are described only as "one of the largest segments of the crowd." 
worked as a motorman for the Toronto Transit Commission and he was also the local reporter for the New York-based Progresso Italo-Americano. Julius Molinaro, together with his brother Frank, grew up as a strong admirer of Italy and all things Italian, a passion that he nurtured through an undergraduate and then two graduate degrees at the nearby University of Toronto. Molinaro completed a very successful career as a professor of Italian Studies at his alma mater, but as an Italian Canadian it was a career that included considerable challenges. Like many others of his era, Molinarø was subjected to harsh treatment in June 1940 when the Italian dictator, Benito Mussolini, declared war on Great Britain and its allies, including Canada.

Many Italian Canadians, often regardless of their citizenship or place of birth, were arrested and eventually over 500 were interned as suspected fascist sympathisers and possible so-called "fifth columnists" or saboteurs, including Julius Molinaro, his father and brother. Ironically, perhaps, after four and one-half months of internment Molinaro went on to serve in the Canadian armed forces and after he was discharged he resumed his career at the University of Toronto. ${ }^{23}$ Clearly, experiences like these had an important effect on Italians not only in Toronto's Little Italy, but also in Canada in general and no doubt influenced-probably with caution and some hesitation-their ability to greet post-war newcomers and to help them negotiate their encounter with the Canadian mainstream.

In the aftermath of World War Two, Italy experienced another mass emigration from the late 1940s to the mid-1970s. Some seven million of its inhabitants departed after the war and about half a million of these made their way to Canada. About 70 percent of this total were from southern Italy. In Italy itself there was a further enormous population shift (generally from south to north) of some 9 million internal migrants. In descending order the post-World War Two emigrants came from the following Italian regions: Calabria, Sicily, Abruzzi, Molise, Latium, Veneto, and Campania. The war itself had served to devastate further an economy already in trouble in the 1920s and 1930s and, as in earlier periods, few Italians could see any hope for the future. At the same time, countries like Canada emerged from the war with a strong need to rebuild sectors of their economies that had been neglected during war time together with the needs of Canadian citizens, in particular returning service people and their families, that also had been held in check because of war-time priorities. As the Canadian economy expanded after the war, then, it experienced a need

23 Molinaro, "Interned Italian Canadians." 
for labour and that need coincided with those in devastated countries like Italy who were weighing their futures.

Beginning first under so-called "bulk labour" programmes sponsored by the government, including a short-lived effort to import young Italian women as domestics, and then increasingly through the mechanism of chain migration and family sponsorships and reunification, annual Italian emigration to Canada grew to unprecedented levels. ${ }^{24}$ The first arrivals in Canada were generally lone males (both married and single) who had contracted for one year of labour before they could be free either to stay or to return. Most if not all chose to stay. In Toronto the primary receiving neighbourhood for this new influx was College Street Little Italy which, over a relatively short period of time, extended its boundaries considerably. These expanded to extend from Bloor Street in the north to Queen Street and beyond in the south and from Bathurst Street in the east to Dovercourt (and beyond) in the west. The arriving Italian immigrants who were responsible for this expansion were arguably the most "visible" of the immediate post-World War Two immigrant influx to Toronto and played an important role in the transformation of the city from "Toronto the Good" to "Toronto the World in a City." From early on both difficulties and challenges were encountered in the accommodation of an ever-growing immigrant population and often were resolved by the immigrants themselves.

One of the most significant challenges was housing. Fortunato Rao arrived in 1952 and settled for a time on Brunswick Avenue, in the top floor of a house shared with a Jewish family. Rao "shopped on Queen Street because College Street was more expensive. ... We shopped at Lombardi's and south on Claremont Street. We were so happy to find Italian products." Later, Rao moved to a residence he shared with a cousin on Clinton Street and nearby, on Manning Avenue, about "twenty-eight men, five per room," lived in one house. The men cooked for themselves on a "stove in the basement with four burners." 25 Of course, these early arrivals would have preferred more substantial and less crowded accommodation but often their means were limited just as their ambitions were focussed on other goals. Within days, if not hours, of their arrival they were at work, intent on putting to use what was often the only resource available to them and the

${ }^{24}$ Iacovetta, Such Hardworking People, in particular the excellent introductory chapters for an overview of post-World War Two Italian immigration to Canada and Toronto.

${ }^{25}$ Rao, The Lucky Immigrant, pp. 31-35. 
only resource that made their emigration possible, their labour. Many of them were intent on paying off debts encountered during their immigration; others struggled to save enough to pay for their families to join them or to be able to marry (often by proxy) and to begin their own families; while still others were already saving money for the all-important purchase of a first home. Thus labourers arriving alone might find accommodation with relatives already housed (albeit themselves saving to move on to better conditions) or share quarters with others from the paese.

Contemporary observers from outside the group (and occasionally even those on the inside), sometimes were shocked by the conditions that they thought prevailed in Little Italy. Fortunately, others went beyond surface appearances in their efforts to understand the lives of those they were describing. In 1961, for example, after a decade of substantial Italian immigration to College Street Little Italy, the late Pierre Berton, accomplished journalist and historian, published a series of three newspaper articles in the Toronto Daily Star in which he described, on the basis of firsthand experience by a colleague, the then Liberal Member of the Provincial Parliament for Dovercourt Riding, Andrew Thompson, the experiences of three newly arrived families. All three families - the Moscones, the Roccos, and the Gasparis - a total of twelve people, shared a narrow (14-foot wide) house with three small apartments and two kitchens between them. Their diet was extremely limited, though the journalist observed "nobody went hungry." One of the families owned a radio and used it sporadically to listen exclusively to Italian-language broadcasting and they had not been to a cinema after their arrival in Canada. All of the immigrants, howevermen, women, and children - who shared this house and this humble lifestyle, worked.

The men leave in the morning, often before $6: 30$ a.m., and do not return until supper. The wives also vanish during the day. Clelia Moscone, for instance, leaves at $7 \mathrm{a} . \mathrm{m}$. to work scrubbing floors ... for $\$ 7$ a day. Mrs. Virgilio Rocco leaves for work at Mario's restaurant at 10:30 a.m. and doesn't return home until six. She leaves again at 11 [p.m.] and works until 3 a.m. She is paid $\$ 25$ a week. Mrs. Ferno [sic] Gaspari ... works in a laundry. Young Natalino Moscone, aged 14, works for 50 cents an hour as a drugstore delivery boy ... His brother, Attilio, is expected to work during the summer holidays as a shoeshine boy. ${ }^{26}$

${ }^{26}$ Cited in Principe, "Introduction: Two Years of Social Unrest"; see also Iacovetta, Such Hardworking People, for more discussion about the economic and other strategies pursued by Italian immigrants in Toronto. 
When the research for the newspaper series was carried out Dominic Moscone was unemployed and had been so for more than 18 months. "For an Italian," Berton concluded, "being unemployed is tragic."

Like the families described here, Rao and other immigrants were intent on "making do" and working hard to achieve their immigrant dreams. Rao continued to live in College Street Little Italy while he worked first in the city's west side, on Roselawn Avenue and then in Scarborough (at Kennedy Road north of Eglinton Avenue), a two-hour commute (4 hours round trip) from Little Italy, and then at Dupont Street and Ossington Avenue, on the border of the Junction settlement, where he was employed by the American Standard Company. For Rao, as for many others, the neighbourhood was a temporary but extremely important sojourn. Within four years of his arrival in Little Italy he had moved on to North York where he settled and where, as early as 1959 , he was able to buy his own home.

As for many others, however, Rao's memories of College Street as the locus for insertion into mainstream society are bittersweet. One of the common experiences, together with housing, employment and other challenges, was the encounter with public space in "Toronto the Good" in the post-World War Two period. According to Rao "we were three or four of us on the sidewalk and saw the police, we would take off because if we stayed they would say, 'Disperse.' ... The police used to say, 'Split it up.' I recall we used to go to the Monarch bar and the other one at Spadina Avenue and College Street and the one at Bloor Street and Brunswick Avenue." 27

This treatment by local authorities seems inconceivable on the streets of contemporary Toronto and above all on the streets of Little Italy where, weather permitting, café life spills onto the sidewalks. That it does so is part of the cultural legacy of those immigrants who eventually protested the treatment they received and were able to introduce new possibilities for Canadian city life. ${ }^{28}$ Despite hostilities of this type, the newcomers found considerable institutional support to meet their needs and quickly began to add to those institutions either by beginning their own enterprises or

\section{${ }^{27}$ Rao, The Lucky Immigrant, pp. 31-35.}

${ }^{28}$ Simonetta interview, for a discussion about Toronto police attitudes towards immigrants who socialized in the streets. Cavaliere Simonetta, a former member of the Italian Carabinieri federal police force, who arrived in the early 1950s, was one of those who intervened (successfully) with the local constabulary against the practice of asking people on the street to "disperse." 
making use of those already in place. New grocery stores and similar enterprises (travel agencies, newsagents, butchers, bakeries and so forth) were added and helped to meet the needs of an expanding population.

The Corriere Canadese appeared on the scene in the early 1950s. Its first newsroom was located at College and Major streets while its editorial office was located to the west at Heydon Park Road and its administrative offices nearby on Brock Avenue near College Street. The first version of the paper appeared as a result of the efforts of men like Arturo Scotti, Gianni Grohovaz, Sam Sorbara, Joseph Carrier and a number of others, some of whom were descendants of the earlier, pre-World War Two immigration. Its first issue appeared in late 1953, but it did not begin to publish on a regular basis until April of the following year by which time it had been taken over by the late Dan Ianuzzi and Arturo Scotti. It has survived and flourished to the present alongside a wide range of more short-lived newspapers like the weekly Panorama, il Giornale di Toronto, il Tevere, Forze Nuove, and many others. ${ }^{29}$ From the pages of these publications we can gain useful insights about daily life in a burgeoning Little Italy.

Theatres in the neighbourhood, for example, were multi-purpose venues where Italian films were screened and a variety of theatrical productions were mounted. The Pylon Theatre (now the Royal) on College Street was one such important venue together with others like the nearby Studio Cinema (at College Street and Manning Avenue) while somewhat further afield entertainment could also be found at the Paradise Cinema on Bloor Street near Dovercourt Road or at the Radio City cinema on St Clair Avenue at Bathurst Street, to name some of the better known. In December 1958, for example, these four cinemas were screening respectively Passione Fatale, Il Bravo di Venezia, I Sogni nel Cassetto, and I Promessi Sposi.30 One new arrival to the neighbourhood (he settled on Markham Street with his sister and brother-in-law in the mid-1950s) saw his first film in Canada "at the Pylon Theatre ... . It was called Il Piccolo Alpino and I had seen it many years before in Chions (Friuli)." Further, the same newcomer remembered that many "singers from Italy, like Claudio Villa, Luciano Taioli, and Nilla Pizzi, to mention just a few, helped to alleviate our homesickness. When the enterprising Johnny Lombardi organized such a show, a sell-out was guaranteed." 31 The local theatres then served

${ }^{29}$ Grohovaz, "Toronto's Italian Press after the Second World War."

${ }^{30}$ Corriere Canadese, various advertisements found in the Tuesday 9 December 1958 issue.

${ }^{31}$ Toppan, The Voice of Labour, p. 44. 
both as cinemas and as venues for dramatic performances or, as noted above, for spectacles sponsored by a number of local impresarios. ${ }^{32}$

Theatrical performances were available almost from the beginning of the post-World War Two immigration to College Street Little Italy. Bruno Mesaglio and others were active from the early 1950s. The Gruppo Filodrammatico of St Agnes, who used the parish hall as their base, was the first such group and on Sunday 6 May 1951, the players presented Eduardo De Filippo's Non ti pago, directed by Ontario Sarracini with "the principal actor ... newcomer Bruno Mesaglio." From this initiative was born the famous Piccolo Teatro Italiano which entertained both newcomers and those more well-established as well as a wider audience drawn from the host saciety. From the early 1950 s to the 1970 s they performed in venues such as the already mentioned cinemas-a production of Morais' L'avvocato difensore, for example, at the Pylon, in 1954, or Goldoni's La locandiera at the same venue in December of 1958-and also in the parish halls of churches like St Agnes or St Mary of the Angels or at Hart House at the University of Toronto or at Brandon Hall (near to St Mary of the Angels). 33

The parish church of St Agnes, served during these years by the Franciscans, was clearly a central institution in the life of the growing Italian neighbourhood after World War Two just as it had been in the inter-war period. Cavaliere Giuseppe Simonetta remembers the church as an essential resource for newly arrived immigrants like himself (1958) for whom it served as an important point of reference while newcomers found their bearings and began to negotiate their entry into the new host society. The mass immigration after World War Two, however, quickly put a great strain on the ability of the Church of St Agnes to serve the needs of its parishioners. ${ }^{34}$ A solution was found, beginning in 1958, with the provision of Italian-language services at the Church of St Francis of Assisi, located at the corner of Mansfield Avenue and Grace Street, near to St Agnes. Eventually, the Italian national parish itself was moved to St Francis in

${ }^{32}$ The role of impresario was also assumed by newcomers like Mr Rocco Mastrangelo who began his business life on College Street shortly after he arrived in 1957 to join his family. His career will be described below in greater detail; see also Mastrangelo interview.

${ }^{33}$ Grohovaz, "A Quest for Heritage." Brandon Hall, or the Italo-Canadian Recreation Centre, located on Brandon Avenue, was the home for Toronto Italia's first community centre, eventually replaced by the present-day Columbus Centre.

${ }^{34}$ Simonetta interview. 
1968 , by which time a number of other churches in the greatly expanded neighbourhood-St Helen, on Dundas Street near its intersection with Lansdowne Avenue, for example and St Anthony on Bloor Street between Dufferin Street and Dovercourt Road-also had begun to offer services in Italian. ${ }^{35} \mathrm{~A}$ few years after the Italian language began to be heard in $\mathrm{St}$ Francis some of its parishioners resumed a type of religious celebration in the form of processions with the statues of saints and other figures from the Roman Catholic tradition-that had formed an important part of their spirituality before immigrating. These began with processions to celebrate the feast of the Madonna of Canneto, of St Francis of Assisi and so forth and from these early undertakings emerged one of the most important and signature events of contemporary College Street Little Italy, the annual Good Friday procession staged during the Roman Catholic Easter observances.

The first of these processions, in 1962, was a rather humble affair organized by a dedicated committee comprised mostly of immigrants from Calabria. ${ }^{36}$ These early processions were held without permission from city authorities but as their size and their popularity spread-with more and more participants in the procession itself and more and more spectators in attendance-it fell to organizers like Cavaliere Giuseppe Simonetta to "legalize" the event with the authorities. The procession has grown to be the largest of its kind in North America with the participation of more than sixty organizations including some who come from other areas of Canada, from the United States, and also from Italy itself. For dedicated volunteers like Simonetta the procession has come to symbolize the postWorld War Two settlement experience in the new world and, in particular, settlement in College Street Little Italy. Today, of course, the procession serves to bring back to the neighbourhood thousands and thousands of immigrants (and their descendants) who have long since left for other corners of the city and beyond. ${ }^{37}$

Ironically perhaps, as the popularity of events such as the Good Friday procession was increasing through the early 1960s, the heyday of College Street Little Italy as an immigrant reception and settlement neighbourhood was already past its prime. The Italian-origin population, using the

${ }^{35}$ Marchetto, "The Catholic Church and Italian Immigration to Toronto: An Overview"; Father Marchetto also notes that Italian-language services ended at St Agnes in 1971.

${ }^{36}$ Simonetta interview.

${ }^{37}$ Simonetta interview. 
boundaries of College and Dundas streets on the north and south and Bathurst Street and Dovercourt Road in the east and west respectively, had grown to roughly 16,500 in a city-wide population of some $140,000.38$ This reality was evident to observers both inside and outside of Little Italy itself. Writing in 1964, for example, a journalist for Maclean's magazine noted that, "Little Italy, if the term is applied to the small, congested areas of stores, movies and streets of closely packed semidetached houses which has its centre around College and Bathurst Streets [sic], and which until 1950 contained most of the Italians in Toronto, is still there. But now it is a funnel through which immigrants pass to an enormous area of Italian concentration one and a half miles wide and four deep that thrusts north through central Toronto beyond the city limits." 39 The same observer was amazed to discover that the "Torontonian prejudices" that had prepared him to see an Italian immigrant either as a labourer in soiled clothing or "as a swarthy, sinister fellow with hooded eyes" were unfounded. Despite this realization, however, and a general sènse of accommodation of the immigrant "other," this was still a host society generation that was shocked by its increasingly widespread encounter with the Italian immigrants in its midst: "Coffee shops are usually noisy with six or seven men of all ages talking endlessly and as if they are all fighting." 40

In the early 1960s then, Italian-style bars or cafés were still described as "coffee shops" in mainstream Canadian society, but this recognition changed over time, in part because of deliberate marketing strategies undertaken by entrepreneurs in Little Italy. The Café Diplomatico (then known as the Bar Diplomatico) is one of the best-known landmarks of contemporary College Street Little Italy and its proprietor, impresario and entrepreneur Mr. Rocco Mastrangelo, after a career of almost 50 years in the neighbourhood, has described with pride his role in introducing the outdoor, sidewalk patio with its signature sun umbrellas when he took over the bar in the late 1960s.41

Mr. Mastrangelo began his career in the neighbourhood in the late 1950 s when he immigrated from his native province of Foggia, in the region of Apulia, to join his family already settled (1952) in Toronto on Grace Street. At first Mastrangelo was dismayed by life in College Street Little Italy. His family, like many others as already discussed, endured

38 Franc Sturino, "Contours of Postwar Italian Immigration to Toronto," p. 130.

${ }^{39}$ Allen, "Portrait of Little Italy," pp. 18.

40 Allen, "Portrait of Little Italy," pp. 44.

${ }^{41}$ Mastrangelo interview. 
crowded housing conditions, a difficult climate, and a less than welcoming host society. Not surprisingly, immediately after his arrival he was determined to return to Italy. Instead, his father challenged him to stay and to make something of himself. Mastrangelo accepted the challenge and in the process, and much to his delight, he grew to appreciate the vitality of the neighbourhood in which he chose to pursue his career and in particular, "the almost folkloric festival of we Italians from all the regions of Italy" who met in College Street Little Italy. In the course of his career in the neighbourhood Mastrangelo has been the proprietor of the Pylon Theatre, Bar Diplomatico, Lansdowne Theatre, and the MVP video and music store and he has also been an impresario, responsible for bringing many famous Italian performers to Toronto.

In the 1960s, however, as his business interests in the neighbourhood were beginning to bear fruit and expanding, he was well aware of the shift that was occurring away from College Street. The Bar Diplomatico, which he established in 1968, was not the first that had appeared in the neighbourhood, but the introduction of the sidewalk patio was an innovation that was soon copied by many others. According to Mastrangelo, however, the patio license by itself was not enough-it was also crucial to have an accompanying liquor license and to encourage, often by paying them modest sums, attractive young women to frequent the patio! 42 Despite successes like these, changes in the neighbourhood continued and indeed accelerated in the course of the 1970s.

One of the generation who had immigrated as a young child in the 1950 s and who grew up in the neighbourhood remembers in vivid detail her childhood experiences and also the changes that she has witnessed is Giovanna Luongo Magni, the very successful restaurateur of Giovanna Trattoria on College Street, a few doors away from its intersection with Grace Street. ${ }^{43}$ Luongo Magni's father arrived in 1952 from the province of Avellino, in the region of Campania, and was followed a year later by his wife and two daughters, including Giovanna. At first they lived in a small house on Nassau Street in Kensington Market. Like many of their contemporaries, after a few years of hard work they were able to buy a house on Clinton Street. Eventually they were able to open their own restaurant on College Street, the Vesuvio, where pizza-perhaps the most famous of

${ }^{42}$ Mastrangelo interview. Other bars in the neighbourhood that had preceded the Diplomatico included the Bar dello Sport, run for a time by Cav. Giuseppe Simonetta, the Capriccio, the Gatto Nero and so forth, Simonetta interview.

${ }^{43}$ Luongo Magni interview. 
all Neapolitan-Italian foods-was introduced to Toronto and which remains one of the specialties of the present-day Giovanna Trattoria.

Luongo Magni remembers in great detail her experiences in school in the neighbourhood beginning with elementary school on Borden Street north of the Market and then moving to Clinton Street where most of her classmates were Jews, reflecting the large number of Jewish Canadians who still resided in the neighbourhood and who would continue to do so until well into the 1960s. She describes College Street Little Italy as "fascinating," a neighbourhood that "started out in the fifties as a landing area where all the Italians came in and then slowly they started moving out. A few of the smart ones stayed behind which was good because real estate went high and they integrated well. They didn't go into areas where they became part of a group, part of a ghetto." Her clientele now is mostly nonItalian in origin and while she feels herself to be completely integrated into mainstream Canadian society she is still upset by being treated as a stereotype rather than being appreciated for the unique (and proud) mixture of cultures that she has become.

As reported in a recent study, the neighbourhood changes observed both by those who have remained as residents or by those who continue to work in the area, after having themselves moved away, were well underway even before Luongo Magni's success with Giovanna Trattoria. In the 1970s, for example, almost 36 percent of a local population of some 34,000 residents according to the Canadian census, was of Italian-ethnic origin, but by the end of the last millennium, that figure had dropped to some 17 percent. ${ }^{44}$ Over the same time period the total of those resident in the area who were born in Italy dropped from 24 to 7 percent-more than a threefold decrease. Perhaps it is not surprising that as this change in the demography of the neighbourhood occurred so too did the density of its settlement change. In fact, the "population density dropped by almost $40 \%$ (after) 1971, owing largely to the substantial renovations to what were once boarding houses and apartments." 45 In other words, new arrivals in the neighbourhood are no longer those immigrants who once endured difficult housing conditions. Having endured, many of those individuals have moved on (more than ninety percent of Italian immigrants in the City of Toronto, for example, now own their own homes) and those who arrive

${ }^{44}$ Hackworth and Rekers, "Ethnic Packaging and Gentrification." The figures cited are based on the boundaries of Bathurst Street and Dovercourt Road in the east and west respectively and Bloor and Dundas streets to the north and south.

45 Hackworth and Rekers, "Ethnic Packaging and Gentrification," pp. 222-223. 
after them are usually intent on "restoring" the housing stock so that they can enjoy the space from which their predecessors profited.

In the 1980s, as these changes were accelerating, a local business improvement association (BIA) was formed. The association's area of interest spanned the city blocks on College Street between Euclid Avenue in the east and Shaw Street in the west. Within this core segment of College Street some 48 percent "of the roughly 154 businesses ... openly identified with Italy or used the Italian language in their names in 1970. By 2000, the percentage had dropped to 29.2 while businesses with no clear ethnic identification became 64.9 percent of the total." 46 The BIA sought to counter some of this decline and it was part of their strategy, enormously successful in retrospect, to preserve some of the flavour of what had gone before or what was disappearing by "branding" College Street itself, and hence the surrounding neighbourhood, as Little Italy. In a bittersweet moment a poet who had grown up in the neighbourhood well before it began to achieve its current popular cachet observed in a poem aptly titled College Street, Little Italy: "1981 / the Italians are almost all gone / to new neighbourhoods / modern towns / ... my father is gone / Bar Italia has a new clientele / women come here now ...." 47 In a similar ironic commemoration of changes that have occurred in the neighbourhood another local poet observes: "I own a house now. / My father sowed his seeds / in his backyard, / and reaped the lettuce and tomatoes / He had known who he was ... In my backyard / I have my grass and flowers / and buy my produce at Dominion. ... ." 48

A different type of poetry - this time written or at least imagined in the Italian language-is at the heart of a romantic comedy in which College Street Little Italy itself might be said to be a protagonist. This poetry is used as a device in the feature film Boy Meets Girl directed by Jerry Ciccoritti, himself a descendant of the post-World War Two immigration to the neighbourhood. Ciccoritti presents Italian-language poetry in the film as the language of love which, together with other varieties of the Italian language (speech as well as gesture, for example), makes possible a romance between an all-Canadian "boy" and an Italian immigrant "girl." On College Street itself, and at least for the second generation in College Street Little Italy, Ciccoritti's film suggests that over a time frame that

${ }^{46}$ Hackworth and Rekers, "Ethnic Packaging and Gentrification," p. 222.

47 Patriarca, "College Street, Little Italy," pp. 73-76; see also Mammone, pp. $205-$ 212.

${ }^{48}$ De Iuliis, “In My Backyard," p. 151. 
stretches from the 1950s through the 1990s, Canada meets and falls in love with Italy in a romance that overcomes language and the barriers to understanding and integration that it can symbolize. In other words, for the second and subsequent generations of Italian Canadians, the College Street neighbourhood and its numerous bars, restaurants, and other venues has become a site for romantic encounters. All suggestion of threat posed by the immigrant "other" has dissipated just as the immigrant language itself (whichever language of Italy it might be) no longer signifies argument: rather, it has become an essential ingredient for love and romance.

Given that we began with the words and insights of Italo Calvino, one of modern Italy's most accomplished authors, himself the child of immigrants, it is appropriate that we end our effort to find an emplotment for a history of Toronto Italia with the words of poets who have themselves closely observed the Italian immigrant experience in Toronto. It remains for the reader to determine whether the emplotment presented here should be categorized as an heroic or tragic or possibly even ironic epic. Regardless of the choice made, it should be clear that the lives of Italian immigrants and their descendants that we have been able to trace, much like Calvino's Ersilians, have left their marks on the present-day city of Toronto. Like the Ersilians, most of those who traced their daily lives across the geography of the neighbourhood of College Street Little Italy and often reached far beyond its boundaries, have moved on to rebuild their "city" elsewhere. What remains is the strings themselves in the words that we are able to retrieve from the immigrants and the supports ${ }^{49}$ for those strings that they put in place.

In fact the "supports," in the form of a variety of different monuments, can be used to map the movement of settlement, generally south to north, by Italian immigrants and their descendants outlined in this study. We can trace these monuments, although not necessarily in chronological order, beginning with a monument sponsored by Italian Canadians and dedicated to multiculturalism. This is located at Union Station in the south of the city, near the lake shore; as one of the most important points of arrival in the city for the immigrant generation this is a location loaded with considerable significance. Moving northward, there is the Italo-Canadese

${ }^{49}$ Principe, "Italian-Canadian Monuments," provides a much more detailed description of the monuments discussed below with the exception of the Lombardi sculpture which was erected after Principe's survey. This 'monumental mode of place-making' ignores other forms of monuments, for example, "ethnic community and social service centre or institution," some of which is discussed in N. Harney, "The Politics of Urban Space." 
plaque on the Edith Cavell memorial already described above, and onwards (always moving north away from Lake Ontario) to the sculpture of Johnny Lombardi (see above) recently installed on College Street itself. Still further north, at the entrance to the city's Piccininni Community Centre, Italian Canadians recently erected a sculpture to commemorate their immigration while at the [Italian-Canadian] Columbus [Community] Centre, still moving north, there is a memorial for those Italian immigrants who are ex-Alpini.50 Further north still, at York University, now on the northernmost boundary of the recently amalgamated City of Toronto, there is an Italian-Canadian monument depicting two solitudes and finally, a monument to Italian-Canadian workers in what is now the furtherst reach (and the most recent concentration) of Italian immigrants and their descendants, the City of Vaughan, on the northern border of Toronto. Perhaps this monument to Italian-Canadian workers marks the creation of a new Ersilia erected by those who left behind their strings and their supports in their previous settlement to the south?

\section{York University}

\section{Works Cited}

\section{Primary Sources}

Corriere Canadese, Tuesday 9 December 1958.

Luongo Magni interview. Angelo Principe and Gabriele Scardellato interview with

Giovanna Luongo Magni, February 2000, author's collection.

Mastrangelo interview. Angelo Principe and Gabriele Scardellato, interview with

Rocco Mastrangelo, January 2000, author's collection.

Simonetta interview. Angelo Principe and Gabriele Scardellato, interview with

Cavaliere Giuseppe Simonetta, January 2000, author's collection.

\section{Published Sources}

Allen, Robert Thomas. "Portrait of Little Italy" Maclean's (21 March 1964): 17$19,43-44,46$.

Anctil, Pierre. "The Immigrant as Text" in If One Were to Write a History: Selected

Writings by Robert F. Harney, eds. Pierre Anctil and Bruno Ramirez. Toronto: Multicultural History Society of Ontario, 1991, pp. vii-ix.

Anon. "An Interview with Mary Caruso" Polyphony: The Bulletin of the Multicultural History Society of Ontario, 6: 1 (1984): 217.

Calvino, Italo. Invisible Cities. New York, NY: Harcourt, 1972, 1974.

${ }^{50}$ See Eisenbichler, "Before the World Collapsed," in this issue of Quaderni. 
De Iuliis, Celestino. "In My Backyard" in Italian Canadian Voices: An Anthology of Poetry and Prose (1946-1983), ed. Caroline Morgan diGiovanni. Oakville: Mosaic Press, 1984, p. 151.

Eisenbichler, Konrad. "Before the World Collapsed Because of the War': The City of Fiume in the Poetry of Gianni Angelo Grohavaz." Quaderni d'italianistica, 28:1 (2007): 115-134.

Gabaccia, Donna. "Global Geography of 'Little Italy': Italian Neighbourhoods in Comparative Perspective" Modern Italy, 11:1 (2006): 9-24.

Grohovaz, Gianni. "Toronto's Italian Press after the Second World War" Polyphony: The Bulletin of the Multicultural History Society of Ontario, 4:1 (1982): 105-113.

Grohovaz, Gianni. "A Quest for Heritage: Piccolo Teatro Italiano" Polyphony: The Bulletin of the Multicultural History Society of Ontario, 5:2 (1983): 47-55.

Hackworth, Jason and Josephine Rekers. "Ethnic Packaging and Gentrification: The Case of Four Neighborhoods in Toronto" Urban Affairs Review, 41 (2005): 211-236.

Harney, N. DeMaria. "The Politics of Urban Space: Modes of Placemaking by Italians in Toronto's Neighbourhoods" Modern Italy, 11:1 (2006): 26-42.

Harney, Robert F. "Chiaroscuro: Italians in Toronto, 1885-1915" Polyphony: The Bulletin of the Multicultural History Society of Ontario, 6:1 (1984): 44-49.

Harney, Robert F. "Ethnicity and Neighbourhoods" in Gathering Place: Peoples and Neighbourhoods of Toronto, 1934-1945, ed. Robert F. Harney. Toronto: Multicultural History Society of Ontario, 1985, pp. 1-24.

Harney, Robert F. "How to Write a History of Toronto Italia" Polyphony: The Bulletin of the Muticultural History Society of Ontario, 7:2 (1986): 61-66.

Harney, Robert F. "The Immigrant City" Vice Versa. Magazine transculturel, 24 (1988): 4-6.

Harney, Robert F. "If One Were to Write a History of Postwar Toronto Italia" in If One Were to Write a History: Selected Writings by Robert F. Harney, eds. Pierre Anctil and Bruno Ramirez. Toronto: Multicultural History Society of Ontario, 1991, pp. 63-86.

Harney, Robert F. "'So Great a Heritage as Ours': Immigration and the Survival of the Canadian Polity" in If One Were to Write a History: Selected Writings by Robert F. Harney, eds. Pierre Anctil and Bruno Ramirez. Toronto: Multicultural History Society of Ontario, 1991, pp. 227-269.

Iacovetta, Franca. Such Hardworking People: Italian Immigrants in Postwar Toronto, Kingston and Montreal: McGill-Queen's University Press, 1992.

Lombardi-Hartig, Donina. "A Man Called Johnny Lombardi" Italian Canadiana, 17 (2003): 97-108.

Mammone, Rita. "Interview with Gianna Patriarca" in Voyages to a New World: Giovanni Caboto and Italian Immigration to Canada / Viaggi Verso il nuovo mondo: Giovanni Caboto e l'immigrazione Italiana in Canada, ed. Gabriele Scardellato. Rome: Promozione e Sviluppo Latina, 1997, pp. 205-212.

Marchetto, Ezio. "The Catholic Church and Italian Immigration to Toronto: An Overview" Polyphony: The Bulletin of the Multicultural History Society of 
Ontario, 7: 2 (1985): 107-110.

Molinaro, Julius. "Interned Italian Canadians Owed Apology" Toronto Star (15 January 1990): A17.

Patriarca, Gianna. "College Street, Little Italy" in The Anthology of ItalianCanadian Writing, ed. Joseph Pivato. Toronto: Guernica Editions, 1998, pp. 73-76.

Perin, Roberto and Gabriele Scardellato, Places of Worship in West Toronto, website forthcoming at http://www.yorku.glendon.

Principe, Angelo. "Italian-Canadian Monuments: A Historical Sketch" in $A$ Monument for Italian-Canadian Immigrants, eds. Manuela Scarci and Gabriele Scardellato. Toronto: Dept. of Italian Studies, University of Toronto and the Italian-Canadian Immigrant Commemorative Association, 1999, pp. 1-31.

Principe, Angelo. "Introduction: Two Years of Social Unrest in Toronto's Little Italy: 1960 \& 1961" in Marino Toppan, The Voice of Labour: A Life in Toronto's Construction Industry, Toronto: (privately printed), c. 2003, pp. 1-33.

Ramirez, Bruno. The Italians in Canada. Ottawa: Canadian Historical Association, 1989.

Rao, Fortunato. The Lucky Immigrant: The Public Life of Fortunato Rao. Toronto: Multicultural History Society of Ontario and the Centre for Instructional Technology Press, 2001.

Simone, Nick. Italian Immigrants in Toronto, 1890-1930. Toronto: Dept. of Geography, York University, 1981.

Sturino, Franc. "Contours of Postwar Italian Immigration to Toronto" Polyphony: The Bulletin of the Multicultural History Society of Ontario, 6:1 (1984): 127130.

Sturino, Franc. Forging the Chain: A Case Study of Italian Migration to North America, 1880-1930. Toronto: Multicultural History Society of Ontario, 1990.

Toppan, Marino. The Voice of Labour: A Life in Toronto's Construction Industry, Toronto: (privately printed), c. 2003.

Zucchi, John. Italians in Toronto: Development of a National Identity, 1875-1935. Kingston and Montreal: McGill-Queen's University Press, 1988. 